DIW BERLIN

Discussion

Papers
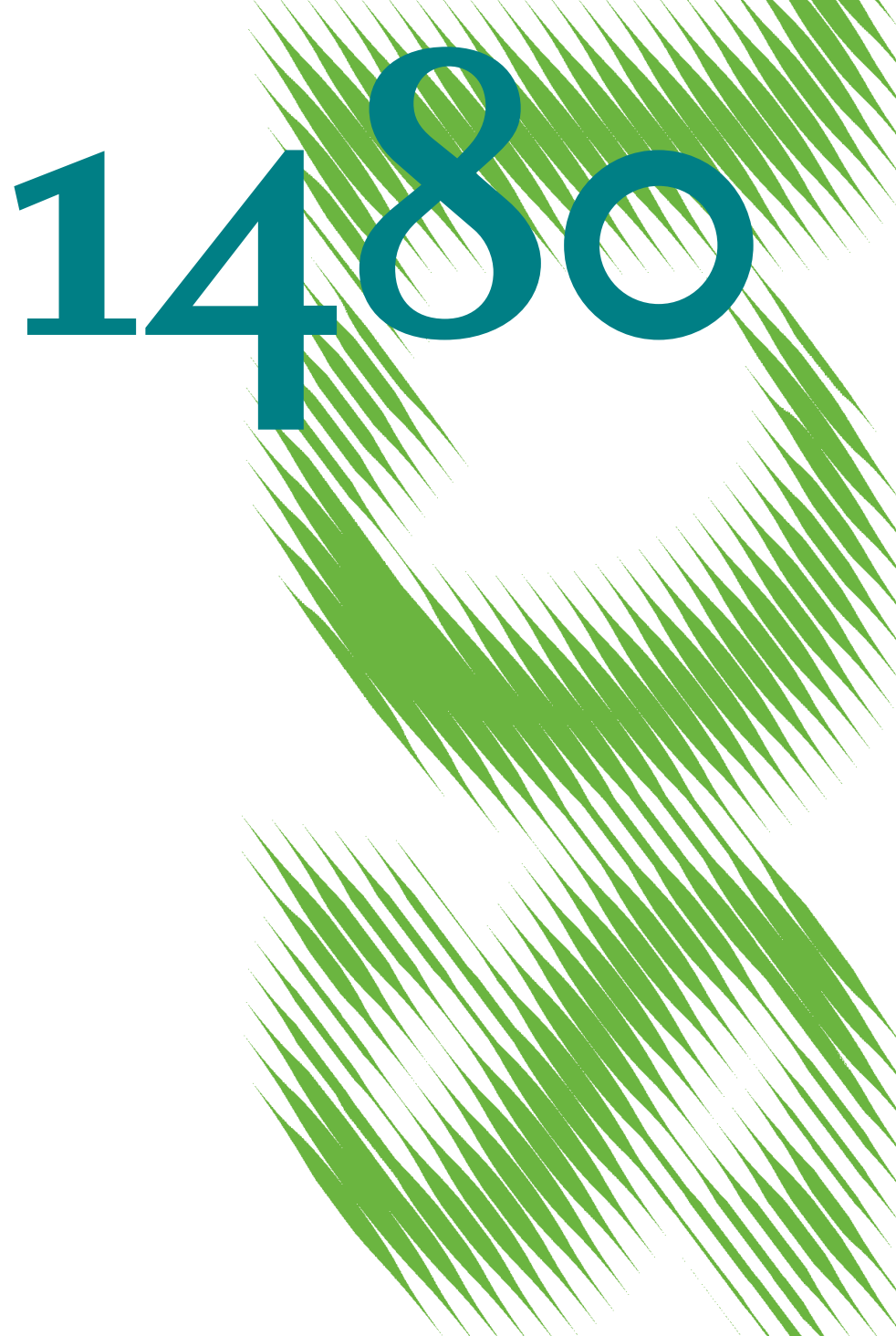

Determinants of Chinese Direct

Investments in the European Union 
Opinions expressed in this paper are those of the author(s) and do not necessarily reflect views of the institute.

IMPRESSUM

(C) DIW Berlin, 2015

DIW Berlin

German Institute for Economic Research

Mohrenstr. 58

10117 Berlin

Tel. +49 (30) $89789-0$

Fax +49 (30) $89789-200$

http://www.diw.de

ISSN electronic edition 1619-4535

Papers can be downloaded free of charge from the DIW Berlin website:

http://www.diw.de/discussionpapers

Discussion Papers of DIW Berlin are indexed in RePEc and SSRN:

http://ideas.repec.org/s/diw/diwwpp.html

http://www.ssrn.com/link/DIW-Berlin-German-Inst-Econ-Res.html 


\title{
Determinants of Chinese Direct Investments in the European Union
}

\author{
Christian Dreger, Yun Schüler-Zhou, Margot Schüller ${ }^{1}$
}

\begin{abstract}
This paper analyses the determinants of Chinese direct investment (DI) in the European Union (EU). Evidence is based on panel Poisson models drawing on two investment monitors for individual projects. We distinguish between the numbers of greenfield investments (GIs) and mergers and acquisitions (M\&As). The findings indicate that market size and trade relationships with China are the primary factors driving Chinese DI in the EU. In contrast, more business-friendly institutions do not foster DI. Chinese enterprises might be risk averse, in other words prefer to choose their activities in regions with less competitive markets. The striking difference between Gls and M\&As is related to unit labour costs. Higher costs make the host country less attractive for the establishment of new firms, but do not affect the involvement in existing firms. The sectoral dispersion of Chinese DI in the EU has not changed much since the global financial crisis of 2008. Most relevant shifts have occurred in research and development (R\&D), where low-income EU countries have gained in attractiveness.
\end{abstract}

JEL: F21, E22, C25

Keywords: China FDI, Greenfield investments, mergers and acquisitions

\footnotetext{
${ }^{1}$ Dreger: DIW Berlin, Mohrenstr. 58, 10117 Berlin, cdreger@diw.de, Schüler-Zhou: GIGA Hamburg, Neuer Jungfernstieg 21, 20354 Hamburg, yun.zhou@giga-hamburg.de, Schüller: GIGA Hamburg, Neuer Jungfernstieg 21, 20354 Hamburg, margot.schueller@giga-hamburg.de.
} 
The European Union (EU) is not only China's most important trading partner but also a very attractive destination for Chinese outward foreign direct investment (OFDI). By entering only one EU member state Chinese firms can access the entire European market. In order to further explore and secure a foothold in this market, Chinese companies already began investing in trade-related fields such as sales and distribution, logistics and maritime transport in Europe during the 1980s. However, not only the significant market size but also the high level of technology in many EU industries has since attracted strategic asset-seeking investments from Chinese multinationals. They target advanced technologies, well-known brands and management practices beneficial for industrial and technological upgrading back home. Chinese OFDI can foster a presence in new markets, accelerate modernization and diversify the huge stock of foreign reserves.

Given that market- and asset-seeking investments have steadily increased over the last decade, many EU countries are now concerned about the influence of Chinese investors. Such investments are largely undertaken by state-owned enterprises (SOEs), where the motives for investment can have a political component to them. Due to the lack of current investment activities in many EU member states, capital inflows from China have become more welcome of late. Especially highly indebted EU countries have decided to sell their state-owned assets, putting downward pressure on their value. The focus of Chinese OFDI has therefore shifted from mainly being natural resources-seeking investments in Asia, Latin America and Africa towards being assets in EU countries - especially those heavily hit by the debt crisis, such as Greece, Portugal and Spain (Hanemann and Rosen, 2012). This trend will likely accelerate over the years to come, as the weak euro makes acquisitions in the monetary union even less costly and given that the Chinese government will continue fostering the going global of the country's companies for the foreseeable future.

-Figure 1 about here-

Although Chinese investments in the EU have increased since the global financial crisis of 2008, their absolute value is still even now rather small. China was the provider of less than 1 percent of the total FDI stock in the EU at the end of 2012. However, the dynamic development is 
impressive. According to the statistics of the Ministry of Commerce (MOFCOM), the cumulative financial value of such investment projects increased from approximately 750 million USD in 2005 to more than 40 billion USD by the end of 2013 (see Figure 1). The annual FDI inflow in the 2005-08 period was about 450 million USD, compared to more than 6 billion USD in the 2010-13 period. This represents a more than tenfold increase. A similar picture emerges if the different modes of market entry, greenfield investments (GIs) and mergers and acquisitions (M\&As), are identified.

This paper investigates the determinants of Chinese direct investment (DI) in the EU. Only a few papers on this research question with a European focus are currently available, even though DI flows from China to the EU have expanded rapidly in recent years. By drawing on two commercial datasets and the panel Poisson approach, the various Gls and M\&As are distinguished from one another. Our findings indicate that the market size and existing trade relationships with China are the primary factors driving Chinese DI decisions in Europe. The sectoral structure of the economy in the host country is only of minor relevance, and more business-friendly institutions do not foster DI on the whole - especially in cases of GI. Chinese enterprises might be risk averse with respect to new foundations, in other words prefer to choose their activities in regions with more restrictive institutions and thus less competitive markets.

The most striking difference between Gls and M\&As can be traced to unit labour costs. Higher costs make the host country less attractive for the founding of new firms, but do not affect the involvement of foreign investors in existing firms. Furthermore, the sectoral dispersion of Chinese DI has not significantly changed since the global financial crisis. Low income countries in the EU, that are the new EU member states, are the main destinations for $\mathrm{DI}$ in manufacturing. In these sectors, cost advantages are of crucial importance. In contrast, Gls in business services and sales, marketing and support are strongly concentrated in high-income countries, namely the traditional EU member states. The most important shift has occurred in the research and development (R\&D) sector. While high-income regions are still the most relevant destinations in this regard, the low-income countries have nevertheless gained in attractiveness in recent years.

To organize our ideas, Section 2 reviews the current state of knowledge about the forces driving Chinese OFDI decisions. Section 3 discusses the databases existing on the subject. Section 4 presents the empirical approach and contains also the results thereof. Section 5 provides fur- 
ther evidence on the regional and sectoral dimensions of investments. Section 6 offers some directions for future research.

\section{$2 \quad$ Locational decisions of Chinese firms}

According to the International Monetary Fund (IMF)'s Balance of Payments manual, FDI is an investment made to acquire long-lasting control over a firm operating in a foreign country. The purpose hereof is to gain an effective voice in the entity's management. A threshold of 10 percent ownership of a company's shares is usually seen as the minimum needed to exert significant influence on that firm's business decisions. Based on the mode of entry, we distinguish between GIs and M\&As. While GI creates new firms and operational facilities from the ground up, M\&A refers to the purchase of already existing firms in the foreign country (Dunning and Lundon, 2008). Making an explicit distinction between GIs and M\&As can contribute to a better understanding of Chinese foreign investment behaviour.

The unique nature of both Gls and M\&As has been largely ignored by previous studies. However, differences between the two strategies are striking. While M\&As may be the better alternative in markets with high competition and well-established incumbent enterprises, Gls may decrease monitoring costs and adverse selection. By exploiting individual firm data, Cozza, Rabelotti and Sanfilippo (2014) argued that Chinese investors can benefit from larger complementarities between domestic and foreign activities due to increases in scale, sales and assets. However, the effects materialize only in the long run and are limited to Gls. In contrast, M\&As lead to a transfer of intangible assets to the Chinese companies involved but the effects thereof disappear after a few years.

From the variety of factors potentially affecting the decision to invest abroad, market size appears to be the most robust - meaning larger markets are expected to attract higher FDI. Other potential candidates, such as labour costs, openness to trade or the industrial structure have been widely discussed in the literature, but the findings with regards to these are much more controversial (Blonigen, 2005). It should be noted that China's institutional setting is different compared to other countries, as Chinese investors operate under specific conditions (Sauvant and Chen, 2013). They usually do not have a competitive advantage over the firms in the host country, even in the case of a Gl. These companies can receive massive political and financial support from the Chinese government in order to be able to compete in a foreign location. 
Amighini, Rabellotti and Sanfilippo (2011) explored host country triggers for Chinese Gls at the industrial level. GI in manufacturing is mainly affected by market-seeking ambitions. In addition, the pattern of Chinese investment differs according to the type of ownership in place (Amighini, Rabellotti and Sanfilippo, 2013). SOEs pursue the strategic needs of their home country and invest more in natural resource sectors, independently of considerations of economic and political stability (Buckley et al 2007). In contrast, private firms are averse to political risk and are primarily attracted by large markets and by the strategic assets offered by potential target markets. Gaining access to natural resources as a primary motive for FDI has been also stressed by Tan (2013) and Urdinez, Masiero and Ogasavara (2014). In contrast, the importance of geographical proximity has declined. For private small and medium-sized enterprises (SMEs) in labour-intensive sectors, lower labour costs are an important motive for investing abroad - especially due to recent higher wage growth in China (Milelli and Sindzingre, 2013). While a high level of industry-specific R\&D activity promotes strategic asset-seeking behaviour, the export experience of a firm and a higher level of industry competition tend to induce market-seeking FDI (Lu, Liu and Wang, 2011).

According to Cheung and Qian (2009), as well as Kolstad and Wiig (2012), the motives for undertaking Chinese FDI differ markedly between developed and developing countries. While capital tends to agglomerate in developed economies, it conversely diversifies among developing economies. Chang (2014) found that Chinese firms prefer to invest in high-tech industries in advanced countries, while they alternately focus on natural resources in emerging countries and resource-rich states such as Canada and Australia. Based on a panel of developing and developed countries, Daly and Zhang (2011) concluded that bilateral and multilateral trade relationships, market size, output growth, exports and resource endowment are the main drivers for Chinese OFDI. By employing GDP per capita and population as indicators for the size of the market in the host country, Rodriguez and Bustillo (2011) detected that both of these variables have a positive impact on the decision to invest abroad. Hence, Chinese investors tend to choose large markets with high purchasing power as their locations - and behave similar to more mature multinationals in this regard.

FDI driven by asset-seeking ambitions looks for more advanced products, technologies and skills than those that are currently available at home. As these inputs mostly belong to mature firms in advanced countries, latecomers like Chinese companies tend to prefer developed economies as their asset-seeking location. Several authors have argued that asset-seeking is one of the key drivers when investing in developed countries (Deng, 2007; Rui and Yip, 2008; 
Schüler-Zhou and Schüller, 2009; Alon et al 2011). However, empirical evidence for this is presently rather scarce.

In applying the number of patents in the host country as a proxy for the endowments of ownership assets, Buckley et al (2007) did not find evidence for asset-seeking behaviour. This result might have been largely generated by the sample time period, as asset seeking will be supported by the Chinese going global policy in the future. Similarly, Rodriguez and Bustillo (2011) detected no significance or even negative impact if country fixed effects are introduced. In contrast, by using gross secondary school enrolment, Amighini, Rabellotti and Sanfilippo (2011) reported a positive effect of human capital availability on Chinese investments in the manufacturing sectors in high- and middle-income countries.

As China possesses competitive advantages with regards to low wages and qualified labour, lower costs are not the main driver for efficiency-seeking OFDI in developed countries. However, with the recent higher wage growth in China efficiency-seeking OFDI is expected to increase in the near future. Cheung and Qian (2009) reported a negative impact of the ratio of host to domestic country wages on Chinese investments, especially in developing countries. According to Hakansson (2013), Northern and Western Europe offer the best locations for asset-seeking Chinese companies, whereas Eastern Europe has attracted Chinese companies whose aim is to access the entire EU market while maintaining the advantages of low costs (Zhang and Filippov, 2009).

Based on the assessment of the particular strengths of the respective industries in each EU country, the Chinese government has issued policy guidelines regarding investment in the region according to countries and sectors. The main industries of specialization are related to the Chinese government's current strategy to increase the sophistication of its exports: standardized commodities and intermediate products will gradually decline in importance in the export portfolio (Pietrobelli, Rabellotti and Sanfilippo, 2011). While Western EU member states are recommended locations for high-tech investment, financial services and R\&D, Eastern EU countries are suggested as destinations for Chinese OFDI in the manufacturing of consumer electronics, textiles and in the tourism industry (Schüler-Zhou, Schüller and Brod, 2012). In contrast to the non-compulsory nature of Western policy guidelines, Chinese companies - and especially SOEs - must take into consideration official recommendations in their crafting of investment strategies. 
Various international organizations compile and publish FDI statistics, such as the OECD, Eurostat, the European Central Bank (ECB), the IMF and the United Nations Conference on Trade and Development (UNCTAD). In China, the MOFCOM, the National Bureau of Statistics and the State Administration of Foreign Exchange have jointly issued an annual 'Statistical Bulletin of China's Outward Foreign Direct Investment' since 2003. This bulletin is compiled in accordance with international standards for FDI statistics: definitions, statistical principles and methodologies are all based on the OECD benchmark definition of FDI and on the IMF Balance of Payments manual.

The activities of Chinese multinationals operating in the EU, and vice versa, are not reported in the country-based FDI statistics, except in those of MOFCOM. However, the MOFCOM data is based only on approved and registered projects. Thus, investments that have escaped formal approval and registration procedures are not captured by these statistics. This applies especially to small-scale investment projects undertaken by privately-owned Chinese firms. Here, the use of two commercial databases (FDI markets and the Zephyr M\&As database) is envisaged as a useful way to explore OFDI impact. Both sets of information provide insights into the overall activities of Chinese multinationals and their foreign affiliates, by using a wide range of indicators like employment, turnover, value added and so on. As the ultimate parent company is reported herein, the information is not distorted by round-tripping and transhipping phenomena.

\section{$4 \quad$ Econometric approach and results}

As only count data is available for both types of investment activity, inference on the macroeconomic determinants is based on Poisson regressions estimated in a panel environment. In general, the Poisson regression is a potential candidate - if the endogenous variable is discrete and restricted to the non-negative area. In addition, the Poisson distribution should hold for both Gls and M\&As. This implies that investment decisions are rare events. Figure 2 illustrates the empirical distributions hereof aggregated over countries and time.

More than 50 percent of the country-time combinations have 0 entries. With an increasing number of investment projects, the frequencies decline fast. This behaviour of the endogenous variable supports the model choice, especially for M\&As. As an alternative, count models 
can be based on the negative binomial approach. However, the additional benefit of using the Poisson model is that the ordered structure of the endogenous variable is kept intact.

-Figure 2 about here-

Both Gls and M\&As are driven by macroeconomic determinants. In particular, the regressors include per capita GDP, openness to trade, relative unit labour costs, the sectoral structure and indicators of institutional conditions in the host countries. Per capita income proxies the market size, meaning larger countries should receive more investment inflows - implying that the impact thereof should be positive. Openness to trade refers to bilateral trade with China, namely Chinese exports plus imports divided by the overall GDP of the host country. Existing relationships with China may spur investment decisions, and therefore the coefficient is expected to be positive. It should be noted, however, that a unique direction of causality is not necessarily implied, as FDI can boost exports and openness at later stages. Lower labour costs in the host country can attract investment seeking for reasons of efficiency, meaning that the effect should be negative. The variable is proxied by real unit labour costs, in other words real wages divided by productivity. Hence, a rise in unit labour costs implies that the real wage increase exceeds advances in productivity. Thus, the measure can avoid possible misinterpretations due to the fact that higher wages might be taken as an indicator for higher productivity or better qualified human capital.

Unit labour costs are expressed relative to the EU average. The sectoral structure is described by the share of the industrial sector in the overall GDP of the host country. This accounts for the fact that Chinese growth was heavily based on industrial expansion in recent years, including the imitation and adaption of products and processes from Western countries. This might lead to a positive impact on the industrial share. Institutional conditions refer to regulatory quality, rule of law, voice and accountability, effectiveness of government, political stability and the control of corruption in the host country. The unweighted average of the institutional components is chosen to save degrees of freedom. In general, the presence of businessfriendly institutions can attract foreign investment. However, this effect may be less relevant for Chinese firms, as EU institutions are in any case far more liberal than they are in the home country. 
Gls are obtained from FDI markets and M\&As from Zephyr, both cross-border investment monitors. Real GDP per capita and real unit labour costs are taken from the AMECO database provided by the EU Commission. Trade with Greater China (Mainland, Hong Kong and Macau) comes from the IMF Directions of International Trade. The industrial share in GDP is taken from the World Bank Development Indicators. Institutional data refers to the World Bank Governance Indicators. While investment projects are discrete and restricted to the non-negative area, per capita GDP is in real terms - meaning divided by the GDP deflator and measured in logs. Openness, relative unit labour costs and the industrial share are expressed as percentages. Institutional indicators are bounded to the $[-2.5,+2.5]$ interval, where higher values imply better institutional quality. Time series are available for the 2003-14 period for all EU countries with the exception of Malta.

-Table 1 about here-

The analysis shows that standard variables are appropriate for explaining both Chinese Gls and M\&As in the EU. As no Hausman test is available for the panel Poisson environment, results for fixed and random effects are reported instead. According to the log likelihood, however, the random effects model can provide a better fit for both types of investment. Taking the standard errors into account, the coefficients are not overwhelmingly different in the FE and RE specifications.

While per capita income and trade relationships with China can attract more Gls and M\&As, the industrial share reveals a negative impact - suggesting that countries with huge industrial sectors receive less investment on average. However this result is not robust, as it is significant only in the Gl fixed effects variant. Therefore, the finding implies that the presence of large industrial sectors is not a necessary precondition to attracting Chinese investment. The institutional variable enters with a negative sign, meaning the presence of more business-friendly institutions does not foster FDI. The coefficient is significant in the GI models and significant at the margin in cases of M\&A. This might indicate that Chinese multinationals are very risk averse; in other words, they prefer to make their Gls and M\&As in regions with probably more restrictive institutions and less competitive markets. The most striking difference between the GI and M\&A models can be traced to real unit labour costs. Higher costs will make the host 
country less attractive for Chinese Gls, but such costs do not have any influence on M\&As. Otherwise, the impact of the variables is quite comparable in the GI and M\&A specifications.

\section{$5 \quad$ The Chinese OFDI approach in different EU regions}

The pattern of Chinese OFDI in Western and Eastern EU countries shows some accordance with the recommendations put forward by the Chinese government. In Western EU countries Chinese investors use M\&As more frequently as the entry mode, probably due to tighter competition in these markets, as they seek access to advanced technologies and well-known brands. In Eastern EU countries, meanwhile, Chinese investors prefer the organic growth achieved through Gls. Eastern EU countries offer significant advantages tied to low-cost but skilled workforces combined with low entry barriers for investment. In terms of the investment value, government-controlled enterprises play a prominent role, while private SMEs dominate in these projects.

Unfortunately, sectoral information across countries is not reported in the time series dimension. However, careful analysis of the Gls database can, at least, provide evidence for two cross sections, both for the period before (2003-08) and after (2009-2014) the global financial crisis. Similar evidence is not available for M\&As. In the following, Gls in four main sectors are considered: manufacturing, business services, sales and marketing (plus support), and research and development. Gls in these areas represent two-thirds of the overall value in the first time period, butslightly less than 40 percent in the second one. Hence, GI diversification has evidently increased over time.

-Figure 3 about here-

Evidence on the regional destinations of GI projects is presented at the level of the four sectors. According to their real GDP per capita, EU countries can be broadly classified into low-, middle- and high-income areas. ${ }^{2}$ The development of the share of GI activities related to dif-

\footnotetext{
2 Per capita GDP in the initial period (2003 and 2009) is relevant in this regard, as it is known by the investors at the time when the GI decision is made. The allocation of countries to the income group is very stable between the two periods. Low-income countries include Bulgaria, Estonia, Croatia, Latvia, Lithuania, Hungary, Poland, Romania and Slovakia. Middle-income countries are the Czech Republic, Greece, Spain, Italy, Cyprus, Portugal and Slovenia. The
} 
ferent income groups is exhibited in Figure 3. Low-income countries, namely usually the new EU member states, are the primary destination for Gls in the manufacturing sector. In contrast, Gls in business services and sales, marketing and support are strongly concentrated in the high-income countries, namely the traditional EU member states. The most important shift between the two periods occurred in R\&D-related activity. While the high-income regions remain the most important destination for it, the low-income countries have recently gained in attractiveness as locations for such endeavours.

\section{$6 \quad$ Beyond OFDI activities}

As the EU is made up of countries with diverse strengths and weaknesses, Chinese companies can set up value chains across the entire region. The MOFCOM's investment guidelines for Chinese investment in Europe suggested adopting different strategies in Western and Eastern EU countries already in 2007. In contrast to the Chinese government's strategic approach to support companies going global, there is no such policy on the EU side. While the EU does have a common trade policy, a unified FDI policy towards China is currently only in the making. The Lisbon Treaty of 2009 assigned competence for a joint FDI policy to the EU Commission and enabled the start of negotiations on an EU-China investment treaty in November 2013. While this bilateral investment treaty (BIT) aims at further facilitating FDI flows in both directions, it not only encompasses the protection of investment but also of market access. The latter issue is of particular interest to European companies investing in China, as they face a number of market entry barriers there at present. For Chinese companies investing in the EU, meanwhile, the EU-China Investment Treaty will offer the benefit of a reduction in transactions costs, associated with the fact that only one single treaty will cover the country's FDI relationship with all 27 of the EU member states. At present, most of the countries in the EU have bilateral investment protection agreements with China and very specific investment promotion programmes. Starting with the global financial crisis, Chinese investment has become more than welcome in EU member states. The competition for FDI from China might constitute an impediment to the EU introducing a consistent FDI policy in the near future.

Although China still plays only a marginal role as an investor in Europe, the recent growth of China's DI in the EU is nevertheless impressive. This trend will continue in the future. Chinese

high-income group encompasses Belgium, Denmark, Germany, Ireland, France, Luxembourg, Netherlands, Austria, Finland, Sweden and the UK. 
sovereign players like the State Administration of Foreign Exchange and the China Investment Corporation have become ever more active in the EU. In addition, investment funds, private equity companies and wealthy individuals from China are increasingly looking to deploy their capital abroad. Utilities and infrastructure will become more attractive targets for financial investments from China. Asset prices are relatively low and investment policies are friendly. Also, Chinese financial investors and sovereign wealth funds are seeking stakes that will provide long-term returns, as recent investments in Greece, Italy and Portugal illustrate. More and more Chinese investors are buying properties in the EU so as to obtain residence permits, especially in countries like Portugal, Greece, Hungary, Latvia and Spain. In Portugal, which runs the most successful residential visa scheme to date, the Chinese are the biggest such buyers. With the rise of China's DI in Europe, mutual dependence will likely increase.

As Chinese DI in Europe has become more diverse, more information will be required on it. Most studies on Chinese OFDI are based on balance of payments statistics. These do not tell us everything about Chinese DI in the EU though. They cover only what is officially considered to be an investment, which is taken to mean cross-border capital flows that entail a significant managerial influence and a long-term investment relationship. The common minimum threshold for a direct investment is 10 percent of a business entity's voting shares. The statistics also do not cover Chinese investment in the sovereign debt of EU member states. Nor do they include the aforementioned purchasing of property in order to obtain a residence permit. In sum, we need fuller data that covers a much broader spectrum than just FDI statistics if we want to know whether the media headline stories of China buying up Europe actually fit the facts. 


\section{References}

Alon I, Child J, Li S, McIntyre JR (2011) Globalization of Chinese firms: Theoretical universalism or particularism. Management and Organization Review 7, 191-200.

Amighini A, Rabellotti R, Sanfilippo M (2011): China's Outward FDI: An industry-level analysis of host country determinants, Frontier of Economics in China 8, 309-336.

Amighini A, Rabellotti R, Sanfilippo M (2013): Do Chinese state-owned and private enterprises differ in their internationalization strategies? China Economic Review 27, 312-325.

Buckley PJ, Clegg LJ, Cross AR, Liu X, Voss H, Zheng P (2007): The determinants of Chinese outward foreign direct investment. International Journal of Business Studies 38, 499-518.

Chang S-C (2014): The determinants and motivations of China's outward foreign direct investment: A spatial gravity model approach, Global Economic Review 43, 244-268.

Cheung Y-W, Qian X (2009): The empirics of China's outward direct investment, Pacific Economic Review 14, 312-341.

Cozza C, Rabellotti R, Sanfilippo M (2014): The impact of outward FDI on the performance of Chinese multinationals, BOFIT Discussion Papers 24/14.

Daly K, Zhang X (2011): The determinants of China's outward foreign direct investment, Emerging Markets Review 12, 389-398.

Deng P (2007): Investing for strategic resources and its rationale: the case of outward FDI from Chinese companies, Business Horizons 50, 71-81.

Dunning JH, Lundan SM (2008): Multinational enterprises and the global economy, 2nd ed, Edward Elgar, Cheltenham.

Hanemann T, Rosen DH (2012): China invests In Europe: Patterns, impacts and policy implications. Rhodium Group New York, http://www.rhgroup.net.

Kolstad I , Wiig A (2012): What determines Chinese outward FDI? Journal of World Business 47, 26-34.

Lu J, Liu X, Wang H (2011): Motives for outward FDI of Chinese private firms: Firm resources, industry dynamics, and government policies, Management and Organizational Review 7, 223248. 
Milelli C, Sindzingre AN (2013): Chinese outward foreign direct investment in developed and developing countries: Converging characteristics? University of Paris West, Economic Working Papers 13-34.

MOFCOM (2014): 2013 Statistical bulletin of China's outward foreign direct investment, Beijing, Ministry of Foreign Commerce.

Pietrobelli C, Rabellotti R, Sanfilippo M (2011): Chinese FDI strategy in Italy: The 'Marco Polo' effect, International Journal of Technological Learning, Innovation and Development 4, 277291.

Rodriguez C, Bustillo R (2011): A critical revision of the empirical literature on Chinese outward investment: A new proposal, Panoeconomicus 5, 715-733.

Rui H, Yip GS (2008): Foreign acquisitions by Chinese firms: A strategic intent perspective. Journal of World Business 43, 213-226.

Sauvant KP, Chen VZ (2013): China's regulatory framework for outward foreign direct investment, East Asian Bureau of Economic Research, Working Paper 88.

Schueler-Zhou Y, Schueller M (2009): The internationalization of Chinese companies: What do official statistics tell us about Chinese outward foreign direct investment? Chinese Management Studies 3, 25-42.

Schueler-Zhou Y, Schueller M, Brod M (2012): Push and pull factors for Chinese OFDI in Europe, in: Alon I, Fetscherin M, Gugler P (eds): Chinese international investments, London, Palgrave Macmillan, 157-174.

Tan X (2013): China's overseas investment in the energy and resources sector: Its scale, drivers, challenges and implications, Energy Economics 36, 750-758.

Urdinez F, Masiero G, Ogasavara M (2014): China's quest for energy through FDI: New empirical evidence, Journal of Chinese Economic and Business Studies 12, 293-314.

Zhang Y, Filippov S (2009): Internationalization of Chinese firms in Europe, UNO-MERIT Working Paper 09-041. 
Figure 1: Chinese OFDI in the EU

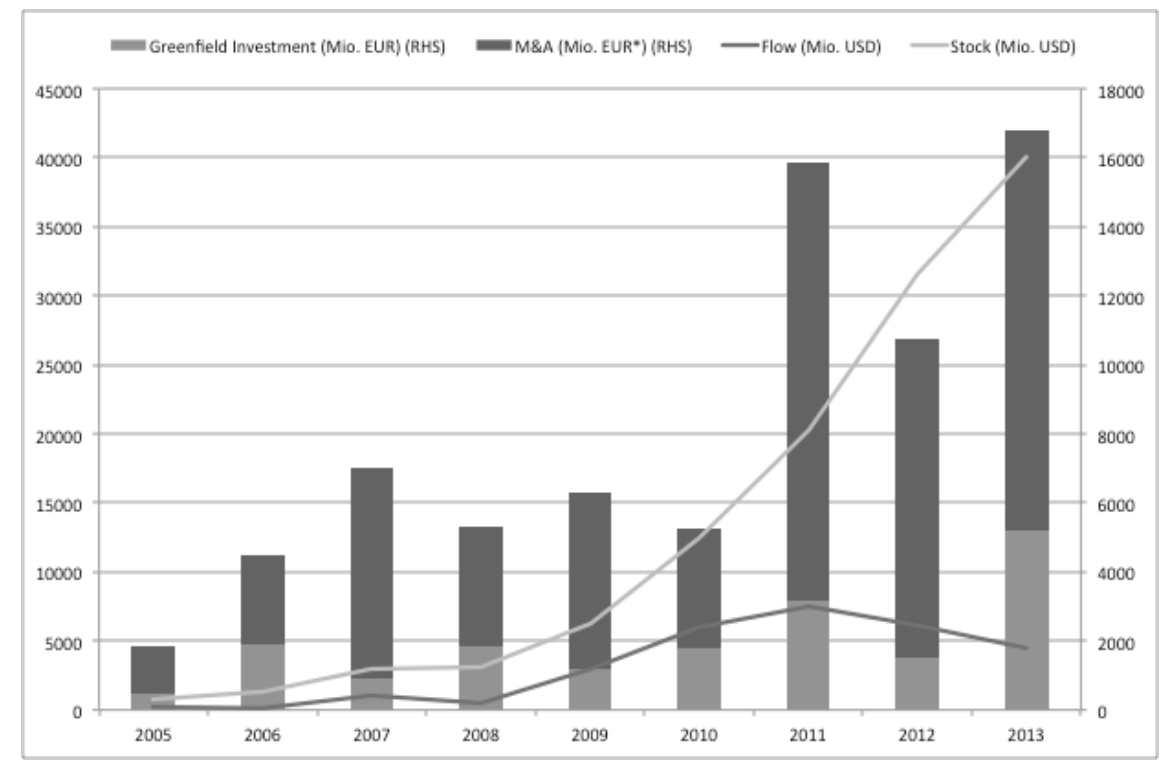

Note: MOFCOM 2013 Statistical Bulletin of China's Outward Foreign Direct Investment, FDI markets (GIs) and Zeph$\mathrm{yr}(\mathrm{M} \& A s)$. M\&A values are estimated, in other words refer to the product of the average transaction value and the number of transactions. 
Figure 2: Empirical distribution of greenfield investments (black) and mergers and acquisitions (grey)

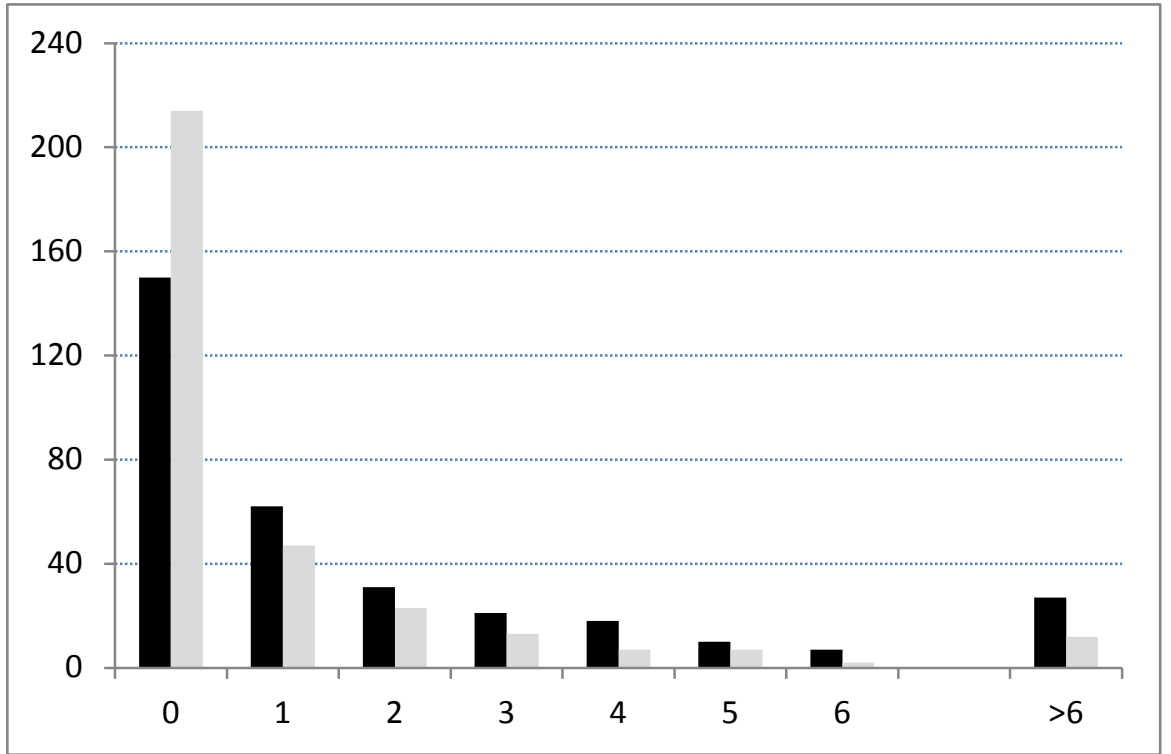

Note: FDI markets (GIs) and Zephyr (M\&As) database. Aggregates over countries and time. Vertical axis plots number of cases. 
Figure 3: Regional destination of Chinese Gl activities

Manufacturing

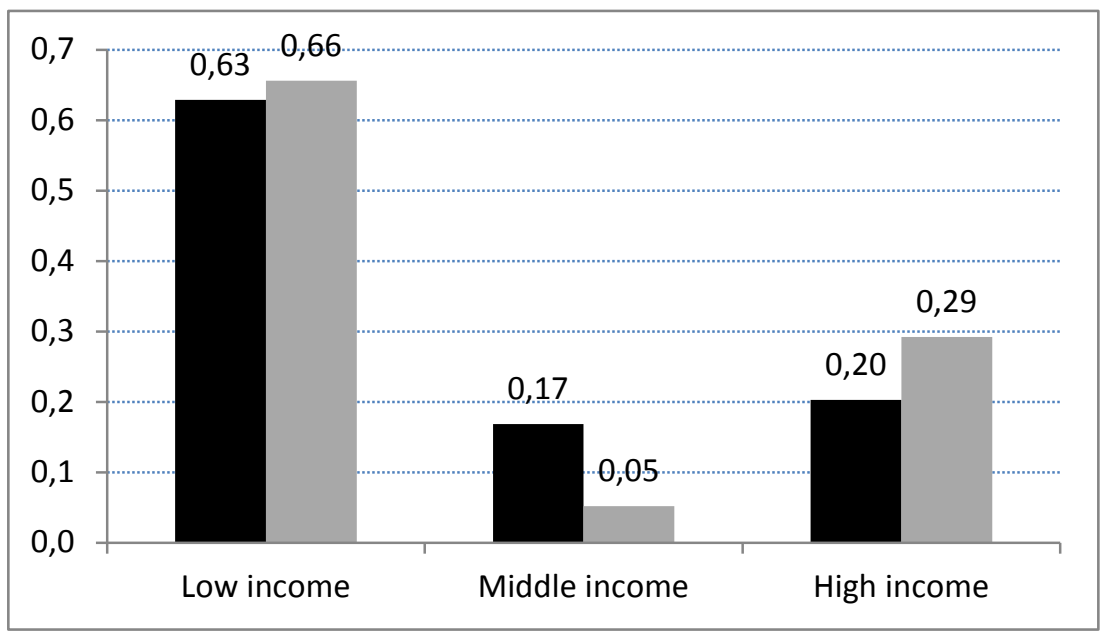

\section{Business services}

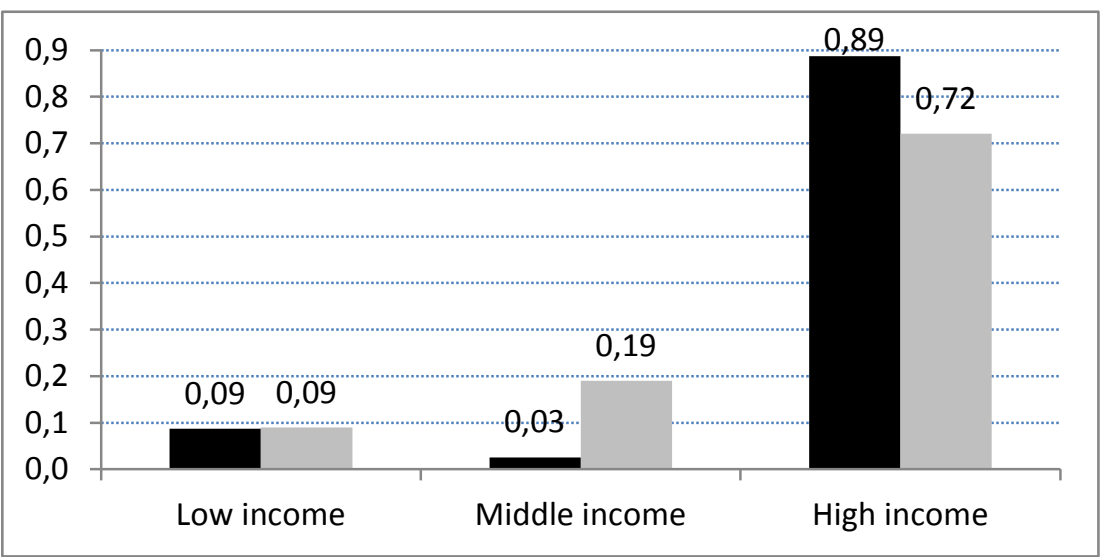

Sales, marketing and support

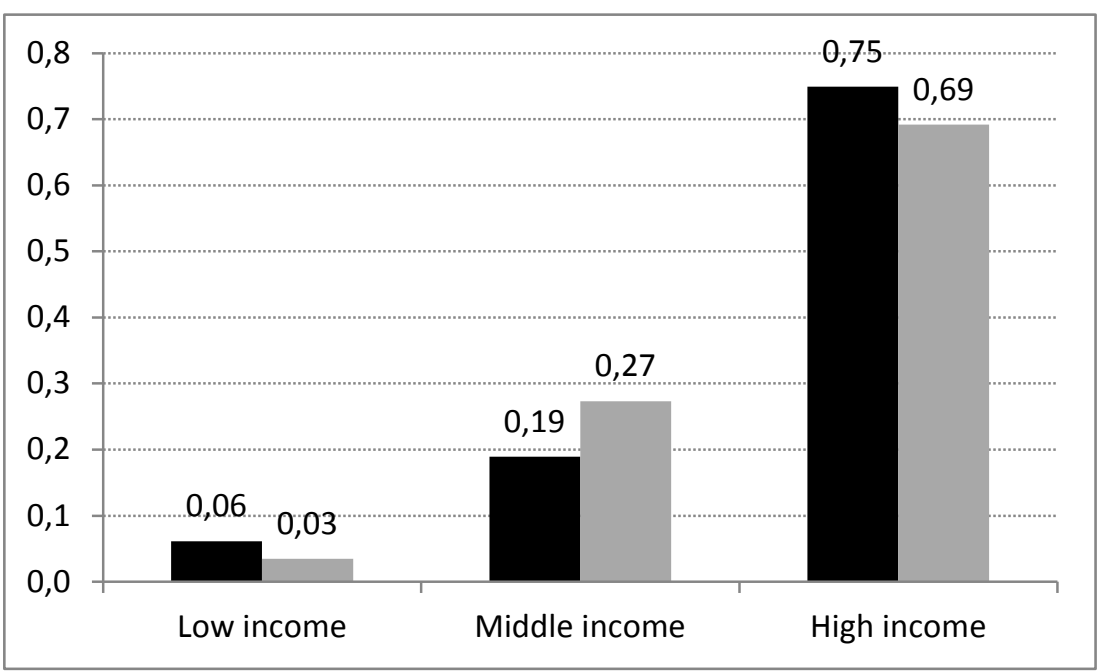




\section{Research and development}

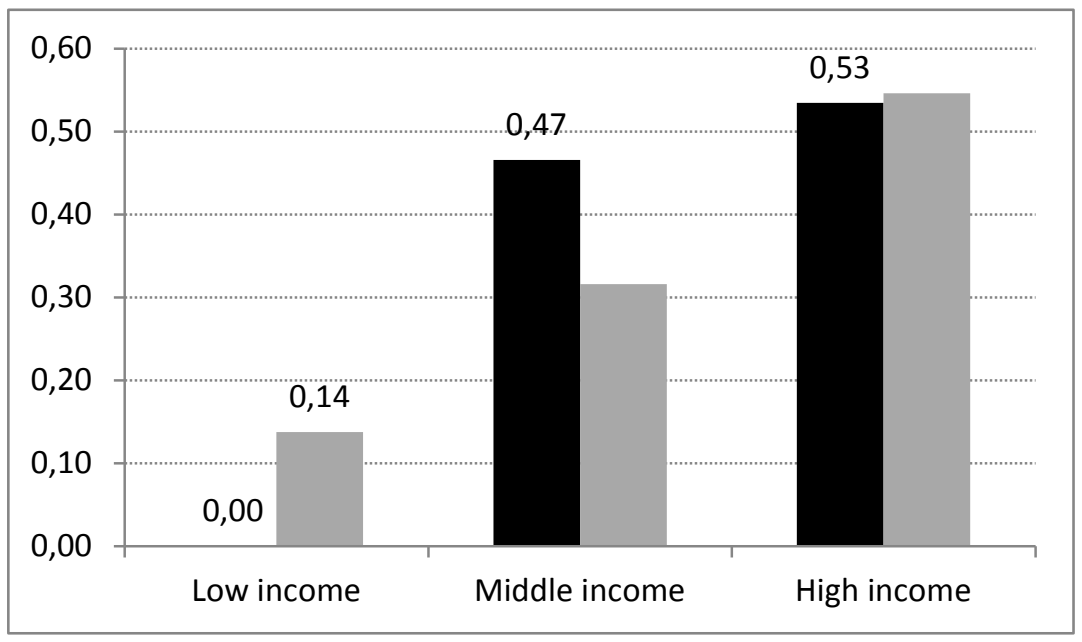

Note: FDI markets. Chinese Gls in 2003-08 (black) and 2009-14 (grey). 
Table 1: Determinants of Chinese foreign investments in the EU

\begin{tabular}{|l|c|c|c|c|}
\hline \multirow{2}{*}{++} & \multicolumn{2}{|c|}{ Greenfield Investments } & \multicolumn{2}{c|}{ Mergers and Acquisitions } \\
\hline & FE & RE & FE & RE \\
\hline \hline Real per capita GDP & $4.676(0.700)$ & $3.172(0.557)$ & $2.724(1.173)$ & $2.104(0.680)$ \\
\hline Trade with China & $0.443(0.040)$ & $0.450(0.039)$ & $0.395(0.074)$ & $0.373(0.067)$ \\
\hline Industrial share & $-0.093(0.033)$ & $-0.026(0.028)$ & $-0.075(0.056)$ & $-0.046(0.037)$ \\
\hline Real unit labour costs & $-0.069(0.017)$ & $-0.050(0.016)$ & $0.026(0.033)$ & $0.035(0.031)$ \\
\hline Institutions & $-2.575(0.721)$ & $-2.837(0.624)$ & $-2.465(1.310)$ & $-1.544(0.861)$ \\
\hline \hline Log likelihood & -418.02 & -540.96 & -215.52 & -300.30 \\
\hline Number of cases & \multicolumn{2}{|c|}{297} & & 231 \\
\hline
\end{tabular}

Note: Panel Poisson regression, 2003-2014. FE = fixed effects, RE = random effects. Standard errors in parentheses. 